\title{
Scaffold Attachment Factor B1
}

National Cancer Institute

\section{Source}

National Cancer Institute. Scaffold Attachment Factor B1. NCI Thesaurus. Code C19674.

Scaffold attachment factor B1 (915 aa, 103 kDa) is encoded by the human SAFB gene.

This protein plays a role in the formation of transcriptional complexes. 